\title{
PERGANTIAN KANTOR AKUNTAN PUBLIK dan FAKTOR-FAKTOR YANG MEMPENGARUHINYA
}

\author{
Hernyke Alviani Sembiring Meliala \\ Ardiani Ika Sulistyawati \\ Prodi Akuntansi Universitas Semarang
}

Riwayat Artikel: Dikirim Agustus 2017; Diterima September 2017; Diterbitkan September 2017

\begin{abstract}
ABSTRAK
Penelitian ini bertujuan untuk menemukan bukti empiris mengenai faktor-faktor yang mempengaruhi pergantian kantor akuntan publik (KAP)pada perusahaan yang terdaftar di Bursa Efek Indonesia (BEI). Variabel yang digunakan dalam penelitian ini adalah pergantian KAP, pergantian manajemen, financial distress, opini auditor, ukuran KAP, dan ukuran klien.

Populasi dalam penelitian in imerupakan seluruh perusahaan yang terdaftar di BEI tahun 20082012.Pemilihan sampel menggunakan metode purposive sampling. Sampel penelitian ini terdiri dari 57 perusahaan yang terdaftar di BEI. Total sampel dalam penelitian ini adalah 285 perusahaan, Hipotesis dalam penelitian ini diuji menggunakan regresi logistik.

Hasil penelitian menunjukkan bahwa pergantian manajemen berpengaruh signifikan terhadap pergantian KAP. Sedangkan variabel financial distress, opini auditor, ukuran KAP dan ukuran klien tidak berpengaruh signifikan terhadap pergantian KAP. Kata Kunci : pergantian kantor akuntan publik, pergantian manajemen, financial distress, opini auditor, ukuran KAP, ukuran klien.

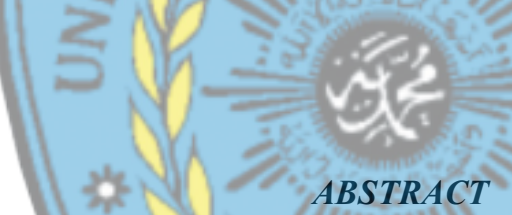

The purpose of this research is to find empirical evidence concerning factors influencingchange of public accounting firmon company that listed in Indonesia Stock Exchange. Variables that is used in this study are management turnover, financial distress, audit opinion, public accountant firm's size, client's size.

The population on this research consist of all listed companies in Indonesia Stock Exchange in year 2008-2012. Selection sample using purposive sampling method. The sample consist of 57 companies that listed on Indonesia Stock Exchange.Total sample in this research are 285 companies. Hypothesis in this research are tested by using logistic regression.

The result of this research showthat management turnover has significant effect on change of public accounting firm. On the other hand, other variables like financial distress, audit opinion, public accountant firm's size, and client's size do not have significant effect on change of public accounting firm.

Keyword :change of public accounting firm, management turnover, financial distress, audit opinion, public accountant firm's size, client's size.
\end{abstract}




\section{PENDAHULUAN}

Setiap perusahaan yang go public memilki kewajiban untuk menyampaikan laporan keuangan baik Badan Pengawas Pasar Modal (Bapepam) maupun bursa. Laporan keuangan tersebut nantinya akan digunakan sebagai dasar untuk pengambilan keputusan oleh para stakeholders. Mengingat pentingnya laporan keuangan tersebut, maka diperlukan jasa akuntan publik untuk memberikan jaminan bahwa laporan keuangan tersebut mempunyai kredibilitas dan bisa memberikan keyakinan terhadap stakeholders.

Dalam menjalankan tugasnya, tiap anggota Kantor Akuntan Publik (KAP) harus memiliki sikap mental independen sebagaimana diatur dalam standar profesional akuntan publik. Auditor harus bersikap independen, maksudnya mereka tidak mudah dipengaruhi karena ia melaksanakan tugasnya untuk kepentingan umum. Agoes (2012) mengungkapkan untuk menjadi independen, auditor harus secara intelektual jujur. Untuk diakui pihak lain sebagai orang yang independen, auditor harus bebas dari setiap kewajiban terhadap kliennya dan tidak mempunyai suatu kepentingan dengan kliennya. Hubungan kerja yang lama dengan perusahaan klien dikhawatirkan akan mengakibatkan seorang auditor kehilangan independensinya karena kemungkinan auditor akan terlibat hubungan pribadi dengan klien. Untuk mengantisipasi hal tersebut, maka perlu diadakan rotasi auditor sesuai peraturan yang berlaku

Indonesia telah memberlakukan adanya kewajiban pergantian KAP. Pemerintah telah mengatur kewajiban pergantian KAP tersebut dengan dikeluarkannya Keputusan Menteri Keuangan Republik Indonesia Nomor 359/KMK.06/2003 tentang "Jasa Akuntan Publik" (pasal 2) sebagai perubahan atas Keputusan Menteri Keuangan Nomor 423/KMK.06/2002 yang isinya antara lain menyebutkan bahwa akuntan publik yang menandatangani laporan audit hanya boleh menangani perusahaan yang sama paling lama tiga tahun, sedangkan KAP dibatasi paling lama lima tahun. Peraturan tersebut kemudian diperbaharui dengan dikeluarkannya Peraturan Menteri Keuangan Republik Indonesia Nomor 17/PMK.01/2008 tentang Jasa Akuntan Publik. Perubahannya ada 2 (dua), yaitu pemberian jasa audit umum oleh KAP paling lama untuk 6 tahun berturut-turut dan oleh akuntan publik paling lama untuk 3 tahun buku berturut-turut pada satu klien yang sama (pasal 3 ayat 1), serta KAP dan akuntan publik boleh menerima kembali penugasan setelah satu tahun buku tidak memberikan jasa audit umum kepada klien tersebut (pasal 3 ayat 2 dan 3) (Susan dan Trisnawati, 2011).

Susan dan Estralita (2011) menyatakan bahwa pergantian auditor dapat dibedakan menjadi pergantian wajib dan pergantian sukarela. Pergantian wajib dilakukan sesuai dengan Keputusan Menteri Keuangan Republik Indonesia sedangkan pergantian sukarela dilakukan apabila klien mengganti auditornya, ketika tidak ada peraturan yang mewajibkannya untuk melakukan pergantian auditor. Dua kemungkinan yang terjadi pada pergantian sukarela ini adalah apabila auditor mengundurkan diri dari penugasan yang diterimanya atau klien mengganti auditor untuk jasa yang diberikan.

Penelitian mengenai pergantian KAP masih sangat menarik untuk diteliti kembali dimana beberapa peneliti telah menguji faktor- faktor yang mempengaruhi penggantian KAP dan memiliki hasil empiris yang berbeda-beda. Faktor- faktor yang menyebabkan perusahaan melakukan

pergantian KAP diantaranya adalah pergantian manajemen. Pergantian manajemen suatu perusahaan dapat mempengaruhi digantinya auditor perusahaan tersebut karena perusahaan akan mencari perusahaan yang menyetujui kebijakan akuntansi yang dipakai oleh manajemen baru dan yang lebih berkualitas. Pratini dan Astika (2013) menemukan bahwa pergantian manajemen berpengaruh signifikan terhadap pergantian KAP. Sama dengan penelitian yang dilakukan oleh Susan dan Trisnawati (2011), Dwiyanti dan Sabini (2014) dan Budi et al. (2015).

Kesulitan keuangan (Financial Distress) juga merupakan faktor yang dapat mempengaruhi pergantian KAP. Perusahaan yang mengalami financial distress dan terancam bangkrut kemungkinan akan mengganti auditornya menjadi yang lebih independen dan berkualitas untuk menarik kepercayaan stakeholders dan menambah kepercayaan diri perusahaan.Hasil penelitian Pratini dan Astika (2013), Dwiyanti dan Sabeni (2014) dan Budi et al. (2015) menyatakan bahwa financial distress berpengaruh terhadap pergantian KAP, sedangkan hasil penelitian Susan dan Trisnawati (2011) menunjukkan hasil yang berbeda, financial distress tidak berpengaruh terhadap pergantian KAP.

Opini auditor merupakan faktor selanjutnya yang mempengaruhi pergantian KAP. Perusahaan klien pada umumnya menginginkan laporan keuangannya mendapat opini wajar tanpa pengecualian dari KAP. Hal tersebut mendorong perusahaan yang mendapat opini yang tidak sesuai dengan keinginannya untuk mengganti auditornya. Penelitian yang dilakukan oleh Pratini dan Astika (2013), Susan dan Trisnawati (2011) dan Juliantari dan Rasmini (2013)mengemukakan 
bahwa opini auditor tidak berpengaruh signifikan terhadap pergantian KAP, akan tetapi berbeda dengan penelitian yang dilakukan Dwiyanti dan Sabeni (2014) mengemukakan bahwa opini auditor berpengaruh signifikan terhadap pergantian KAP.

Faktor lain yang mempengaruhi pergantian KAPadalah ukuran KAP. Nasser et al. (2006) dalam Juliantari dan Rasmini (2013) mengungkapkan bahwa KAP big-4 diketahui memiliki kemampuan untuk menjaga tingkatan independensi daripada KAP non big-4, karena mereka biasanya menyediakan cakupan jasa-jasa ke sejumlah besar klien. Hasil penelitian yang dilakukan oleh Pratini dan Astika (2013) mengemukakan bahwa ukuran KAP tidak berpengaruh signifikan terhadap pergantian KAP. Berbeda dengan penelitian yang dilakukan oleh Susan dan Trisnawati (2011), Juliantari dan Rasmini (2013) dan Budi et al. (2015) yang mengemukakan bahwa ukuran KAP berpengaruh terhadap pergantian KAP.

Selain daripada pergantian manajemen, financial distress, opini auditor dan ukuran KAP, ukuran klien juga merupakan faktor yang mempengaruhi pergantian KAP. Perusahaan klien yang besar memiliki kompleksitas usaha, dan peningkatan sejumlah konflik yang dapat menimbulkan biaya keagenan, sehingga permintaan yang sangat tinggi bagi perusahaan audit independen untuk mengurangi biaya keagenan (Juliantari dan Rasmini, 2013). Penelitian yang telah dilakukan oleh Juliantari dan Rasmini (2013), Dwiyanti dan Sabeni (2014) dan Budi et al. (2015) seluruhnya berhasil membuktikan bahwa ukuran perusahaan klien berpengaruh pada pergantian KAP.

Penelitian ini mencoba mengembangkan penelitian Pratini dan Astika (2013). Perbedaan pada penelitian ini bahwa penelitian yang dilakukan oleh Pratini dan Astika (2013) menggunakan objek penelitian pada perusahaan manufaktur yang terdaftar di BEI tahun 2008 sampai dengan 2011, sedangkan penelitian ini menggunakan objek penelitian pada seluruh perusahaan yang listing di BEI tahun 2008 sampai dengan tahun 2012.

Pada penelitian Pratini dan Astika (2013) variabel yang digunakan antara lain pergantian manajemen, financial distress, opini audit, dan ukuran KAP, sedangkan Penelitian ini menambahkan variabel independen yaitu ukuran klien. Penambahan variabel tersebut dikarenakan saran dari penelitian sebelumnyaPratini dan Astika (2013) yang dapat menjadi pertimbangan penelitian.Selain itu variabel tersebut berpengaruh positif terhadap pergantian KAPpada penelitian terdahulu.
Berdasarkan uraian latar belakang di atas, maka rumusan masalah dalam penelitian ini adalah:

1. Apakah faktor pergantian manajemen mempengaruhi perusahaan melakukan pergantian Kantor Akuntan Publik?

2. Apakah faktor financial distress mempengaruhi perusahaan melakukan pergantian Kantor Akuntan Publik?

3. Apakah faktor opini auditor mempengaruhi perusahaan melakukan pergantian Kantor Akuntan Publik?

4. Apakah faktor ukuran kantor akuntan publik mempengaruhi perusahaan melakukan pergantian Kantor Akuntan Publik?

5. Apakah faktor ukuran klien mempengaruhi perusahaan melakukan pergantian Kantor Akuntan Publik?

\section{TELAH PUSTAKA}

\section{Pengaruh Pergantian Manajemen Terhadap} pergantian Kantor Akuntan Publik Juliantari dan Rasmini (2013) menyatakan bahwa jika suatu perusahaan mengganti manajemennya maka akan memungkinkan klien untuk memilih auditor baru yang lebih berkualitas dan sepakat dengan kebijakan akuntansi perusahaan.

Lebih lanjut, Damayanti dan Sudarma (2010) dalam Pratini dan Astika (2013) menyatakan bahwa pergantian manajemen dapat disebabkan karena pihak manajemen berhenti karena kemauan sendiri atau keputusan rapat umum pemegang saham, sehingga pemegang saham harus melakukan pergantian manajemen yang baru yaitu direktur utama atau Chief Executive Officer (CEO). Dengan adanya CEO yang baru mengakibatkan perubahan pada kebijakan di dalam perusahaan seperti dalam bidang akuntansi keuangan dan pemilihan sebuah KAP karena perusahaan cenderung akan memilih auditor baru yang sepakat dengan kebijakan baru di perusahaan mereka.

Manajemen lebih sering mengganti akuntan publiknya karena unsur kepercayaan. Jika manajemen yang baru yakin bahwa akuntan publik yang baru bisa diajak kerja sama dan lebih bisa memberikan opini seperti harapan manajemen disertai dengan adanya preferensi tersendiri tentang auditor yang akan digunakannya, pergantian akuntan publik dapat terjadi dalam perusahaan (Wahyuningsih dan Suryanawa, 2012). Hal tersebut sesuai dengan penelitian Pratini dan Astika (2013) yang menyatakan bahwa pergantian manajemen berpengaruh positif terhadap pergantian KAP.

\section{Rumusan Masalah}


Dari uraian yang telah dijelaskan dapat dirumuskan hipotesis sebagai berikut:

H1 : Pergantian Manajemen berpengaruh terhadap pergantian Kantor Akuntan Publik

\section{Pengaruh Financial Distress Terhadap pergantian Kantor Akuntan Publik}

Financial distress merupakankondisi di mana perusahaan mengalami kondisi yang tidak sehat ataupun kesulitan dalam keuangan sehingga dikhawatirkan akan mengalami kebangkrutan. Whitaker (1999) dalam Dwiyanti \& Sabeni (2014) menjelaskan bahwa perusahaan mengalami financial distress antara lain ditandai dengan adanya pemberhentian tenaga kerja atau hilangnya pembayaran deviden, serta arus kas yang lebih kecil daripada hutang jangka panjang.

Kondisi perusahaan yang berpotensi bangkrut memiliki kecenderungan mengganti auditor karena di dalam lingkungan perusahaan yang sedang mengalami potensi kebangkrutan terdapat pengaruh yang besar pada ketegangan hubungan antara manajemen dan auditor yang menyebabkan putusnya hubungan kerja antara manajemen dan auditor (Schwartz dan Menon, 1985) dalam Budi, 2015). Klien yang sedang mengalami financial distress kemungkinan akan mengganti auditornya menjadi yang lebih independen dan berkualitas untuk menarik kepercayaan stakeholders dan menambah kepercayaan diri perusahaan. Perpindahan Kantor Akuntan Publik juga bisa disebabkan karena perusahaan sudah tidak lagi memiliki kemampuan untuk membayar biaya audit yang dibebankan oleh KAP yang diakibatkan penurunan kemampuan keuangan perusahaan (Kurniaty et al., 2014).Hipotesis yang dirumuskan dari uraian diatas:

H2 : Financial Distress berpengaruh terhadap pergantian Kantor Akuntan Publik

\section{Pengaruh Opini Auditor Terhadap pergantian Kantor Akuntan Publik}

Opini audit merupakan hasil akhir atau muara dari suatu proses audit atas laporan keuangan klien yang bisa dijadikan sebagai acuan atau dasar bagi pihak pengambil keputusan ekonomik atas keandalan informasi yang ada dalam laporan keuangan klien dan juga merupakan pertanggungjawaban bagi auditor atas opini yang telah diberikan kepada klien (Kurniaty et al., 2014).

Manajemen umumnya mengharapkan

untuk memperoleh opini wajar tanpa pengecualian (unqualified opinion) atas hasil pemeriksaan oleh auditor terhadap laporan keuangan yang disusunnya. Akan tetapi, tidak jarang perusahaan memperoleh opini wajar dengan pengecualian (qualified opinion). Bahkan bukan hal yang mustahil bagi perusahaan untuk memperoleh disclaimer opinion atau adverse opinion (Surampaet, 2010). Jika auditor memberikan opini yang kurang baik, hal tersebut cenderung akan mendorong perusahaan untuk mengganti auditornya dengan auditor yang dapat memberi opini yang baik. Jadi dapat disimpulkan bahwa klien yang tidak mendapat opini audit yang diharapkan akan cenderung mengganti KAP.

Hal tersebut didukung oleh penelitian Dwiyanti dan Sabini (2014) yang menemukan bukti empiris bahwa opini audit mempunyai pengaruh positif terhadap pergantian KAP. Hipotesis yang dirumuskan dari uraian diatas: H3: Opini auditor berpengaruh terhadap pergantian Kantor Akuntan Publik

\section{Pengaruh Ukuran KAP terhadap pergantian Kantor Akuntan Publik}

Ukuran dari KAP digolongkan dalam big-4 dan non big-4. KAP big-4 dianggap lebih mampu meningkatkan indepedensi dibandingkan KAP yang kecil dan KAP non big-4 diaggap memiliki tingkat independensi lebih rendah daripada KAP big-4. Nasser et al. (2006) dalam Budi (2015) mengungkapkan bahwa KAP yang lebih besar (Big-4) dianggap lebih mampu mempertahankan tingkat independensi yang memadai daripada rekan-rekan mereka yang lebih kecil karena mereka dapat menyediakan berbagai layanan untuk klien dalam jumlah yang lebih besar, sehingga mengurangi ketergantungan mereka pada klien tertentu. Selain itu, KAP yang lebih besar umumnya juga dianggap sebagai penyedia kualitas audit yang tinggi dan menikmati reputasi tinggi dalam lingkungan bisnis dan karena itu, akan berusaha untuk mempertahankan independensi mereka untuk menjaga image mereka (Buchari dan Marita, 2014).

Dari penjelasan diatas maka dapat disimpulkan bahwa perusahaan cenderung akan mengganti KAP menjadi KAP big 4 untuk mendapatkan audit yang lebih baik dan berkualitas. Hal tersebut sesuai dengan penelitian yang dilakukan oleh Susan dan Trisnawati (2011), Juliantari dan Rasmini (2013) dan Budi et al. (2015) yang mengemukakan bahwa ukuran KAP berpengaruh terhadap pergantian KAP. Hipotesis yang dirumuskan dari uraian diatas:

H4: Ukuran KAP berpengaruh terhadap pergantian Kantor Akuntan Publik

\section{Pengaruh Ukuran Klien terhadap pergantian}

\section{Kantor Akuntan Publik}

Ukuran besar atau kecilnya suatu perusahaan dapat dilihat berdasarkan total aktivanya. Semakin besar total aktiva suatu perusahaan, maka semakin besar pula ukuran perusahaan tersebut. Hudaib dan Coke (2005) dalam Juliantari dan Rasmini (2013) menyatakan 
bahwa ketidaksesuaian ukuran antara perusahaan klien yang besar diaudit oleh perusahaan audit yang kecil dapat menyebabkan berakhirnya keterlibatan audit, yaitu pergantian Kantor Akuntan Publik (KAP).

Auditee yang lebih besar mempunyai operasional yang kompleks, adanya pemisahan antara manajemen dan kepemilikan sangat memerlukan KAP yang dapat mengurangi agency cost. KAP yang berkualitas sangat diperlukan untuk meningkatkan kredibiltas perusahaan (Budi, 2015). Oleh sebab itu, perusahaan besar akan mengganti auditornya dengan auditor dari KAP yang lebih besar yang mereka anggap lebih mampu memeriksa laporan keuangannya. Hal tersebut sesuai dengan penelitian yang telah dilakukan oleh Juliantari dan Rasmini (2013), Dwiyanti dan Sabeni (2014) dan Budi et al. (2015) yang mengemukakan bahwa ukuran klien berpengaruh terhadap pergantian KAP. Berdasarkan argumentasi tersebut maka hipotesis kelima dalam penelitian ini dirumuskan dalam bentuk alternatif bahwa:

H5: Ukuran klien berpengaruh terhadap pergantian Kantor Akuntan Publik

Gambar 1 berikut menggambarkan kerangka penelitian:

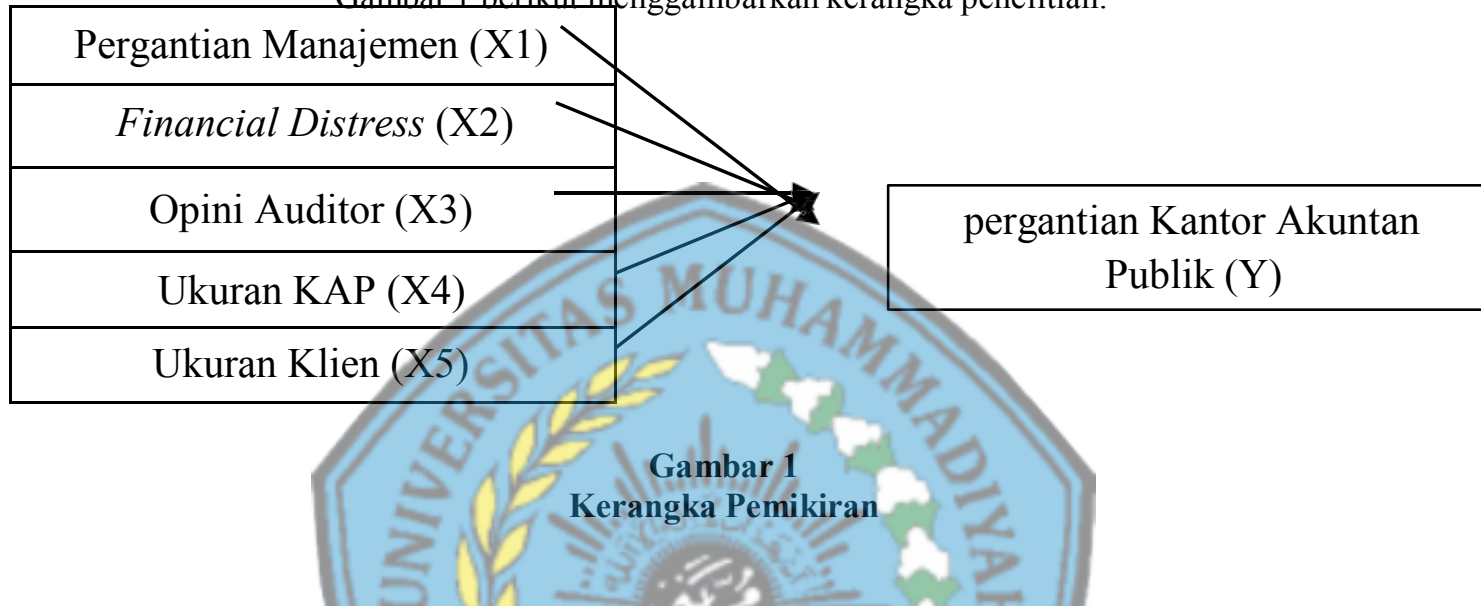

METODE PENELITIAN

\section{Populasi dan Sampel}

Populasi dalam penelitian ini adalah seluruh perusahaan publik di Indonesia yang terdaftar di Bursa Efek Indonesia (BEI) dari tahun
2008 - 2012. Sampel dalam penelitian ini dipilih dengan menggunakan metode purposive sampling.Jumlah sampel dalam penelitian ini adalah sebanyak 57 perusahaan untuk masingmasing periode.

\section{SENARANG}

Tabel 1

Proses Seleksi Sampel Berdasarkan Kriteria

\begin{tabular}{|l|c|}
\hline \multicolumn{1}{|c|}{ Keterangan } & Jumlah \\
\hline Jumlah perusahaan yang listing di BEI dari 2008-2012 & 383 \\
\hline Perusahaan yang delisting tahun 2008-2012 & $(15)$ \\
\hline $\begin{array}{l}\text { Perusahaan tidak menyajikan informasi lengkap sesuai dengan yang dibutuhkan } \\
\text { dalam penelitian }\end{array}$ & $(77)$ \\
\hline Jumlah sampel perusahaan & $\mathbf{5 7}$ \\
\hline Tahun amatan & $\mathbf{5}$ \\
\hline Jumlah total sampel & $\mathbf{2 8 5}$ \\
\hline
\end{tabular}

Jenis dan Sumber Data
Jenis data yang digunakan dalam penelitian ini adalah data sekunder, yaitu data 
yang diperoleh dari pihak lain yang berkaitan atau berhubungan dengan data yang akan di ambil. Data sekunder dalam penelitian ini bersumber dari laporan keuangan yang telah diaudit pada seluruh perusahaan publik yang terdaftar dalam BEI dari tahun 2008-2012 yang telah dipublikasikan. Data dalam penelitian ini juga diperoleh dari www.idx.co.id.

\section{Metode Pengumpulan Data}

Pengumpulan data yang dilakukan adalah dengan menggunakan metode dokumentasi dari sumber yang digunakan yaitu laporan keuangan perusahaan sampel yang sudah diaudit.

\section{Metode Analisis}

\section{Statistik Deskriptif}

Gambaran suatu data secara umum sering juga disebut dengan statistik deskriptif. Analisis frekuensi, statistik deskripsi, eksplorasi data, tabel silang, analisis rasio, P-P Plots, dan QQ Plots merupakan bagian dari analisis statistik deskriptif. Analisis yang di gunakan dalam penelitian ini adalah menggunakan analisis frekuensi. Analisis frekuensi memiliki beberapa keguanaan antara lain untuk menentukan pengecekan terhadap data yang diinput apakah sudah benar atau belum, dan menyediakan informasi deksripsi data yang menggambarkan demographic characteristics dari sampel yang diambil.

\section{Uji Keseluruhan Model (Overall Model Fit)}

Langkah pertama adalah menilai overall model fit terhadap data. Beberapa tes statistik diberikan untuk menilai hal ini. Hipotesis untuk menilai model fit adalah:

$\mathrm{H}_{0} \quad$ : Model yang dihipotesiskan fit dengan data

$\mathrm{H}_{\mathrm{a}} \quad$ : Model yang dihipotesiskan tidak fit dengan data.

Dari hipotesis ini jelas bahwa kita tidak akan menolak hipotesis nol agar model fit dengan data.

Uji Kelayakan Model Regresi (Hosmer and Lemeshow's Goodness of Fit Test)

Uji kelayakan model regresi dinilai dengan menggunakan Hosmer and Lemeshow's Goodness of Fit Test. Hosmer dan Lemeshow's (HL) ini menguji hipotesis nol bahwa tidak ada perbedaan antara model dengan data sehingga model dapat dikatakan fit. Jika nilai HL Goodness of Fit test statistics sama dengan atau kurang dari 0,05 , maka hipotesis nol ditolak yang berarti ada perbedaan signifikan antara model dengan nilai observasinya sehingga Goodness of fit model tidak baik karena model tidak dapat memprediksi nilai observasinya. Jika nilai statistik HL lebih besar dari 0,05, maka hipotesis nol tidak dapat ditolak dan berarti model mampu memprediksi nilai observasinya atau dapat dikatakan model dapat diterima karena cocok dengan data observasinya (Ghozali, 2011).

\section{Koefisien Determinasi (Nagelkerke R Square)}

Cox dan Snell's $R$ Square merupakan ukuran yang mencoba meniru ukuran $\mathrm{R}^{2}$ pada multiple regression yang didasarkan pada teknik estimasi likelihood dengan nilai maksimum kurang dari 1 (satu) sehingga sulit diinterpretasikan. Nagelkerke's $R$ square merupakan modifikasi dari koefisien Cox dan Snell untuk memastikan bahwa nilainya bervariasi dari 0 (nol) sampai 1 (satu). Hal ini dilakukan dengan cara membagi nilai Cox dan Snell's $\mathrm{R}^{2}$ dengan nilai maksimumnya. Nilai Nagelkerke's $\mathrm{R}^{2}$ dapat diinterpretasikan seperti nilai $\mathrm{R}^{2}$ pada multiple regression (Ghozali, 2011).

Pengujian Hipotesis Penelitian Penelitian ini dilakukan dengan menggunakan nilai signifikansi level sebesar 5\% untuk mengetahui apakah ada pengaruh nyata dari variabel independen terhadap variabel dependen. Kriteria dari pengujian ini, yaitu:

1. Signifikansi level (Sig.) $>0,05$; maka terima $\mathrm{H}_{0}$ dan tolak $\mathrm{H}_{1}$

2. Signifikansi level (Sig.) $<0,05$; maka tolak $\mathrm{H}_{0}$ dan terima $\mathrm{H}_{1}$

Model Regresi yang Terbentuk Adapun model regresi dalam penelitian ini adalah sebagai berikut:

SWITCH $H_{t}=b_{o}+b_{1}$ CEO $+b_{2}$ FDIS $+b_{3}$ OPINI + $\mathrm{b}_{4} \mathrm{SIZE}+\mathrm{b}_{5} \mathrm{LnTA}+\mathrm{e}$

Keterangan:

SWITCH

$\mathrm{b}_{\mathrm{o}}$

: auditor switching

$\mathrm{b}_{1}-\mathrm{b}_{5} \quad:$ koefisien regresi

: konstanta

CEO : pergantian manajemen

FDIS : financial distress

OPINI : opini audit

SIZE : ukuran KAP

LnTA :ukuran Perusahaan klien

e :eror

\section{HASIL DAN PEMBAHASAN}

\section{Analisis Data}




\section{Analisis Frekuensi}

\section{Tabel Hasil Analisis Frekuensi}

\begin{tabular}{|l|}
\hline \multicolumn{1}{|c|}{ Valid } \\
\hline \multicolumn{1}{|c|}{ Missing } \\
Mean \\
Median \\
Mode \\
Std. Deviation \\
Variance \\
Range \\
Minimum \\
Maximum \\
Sum
\end{tabular}
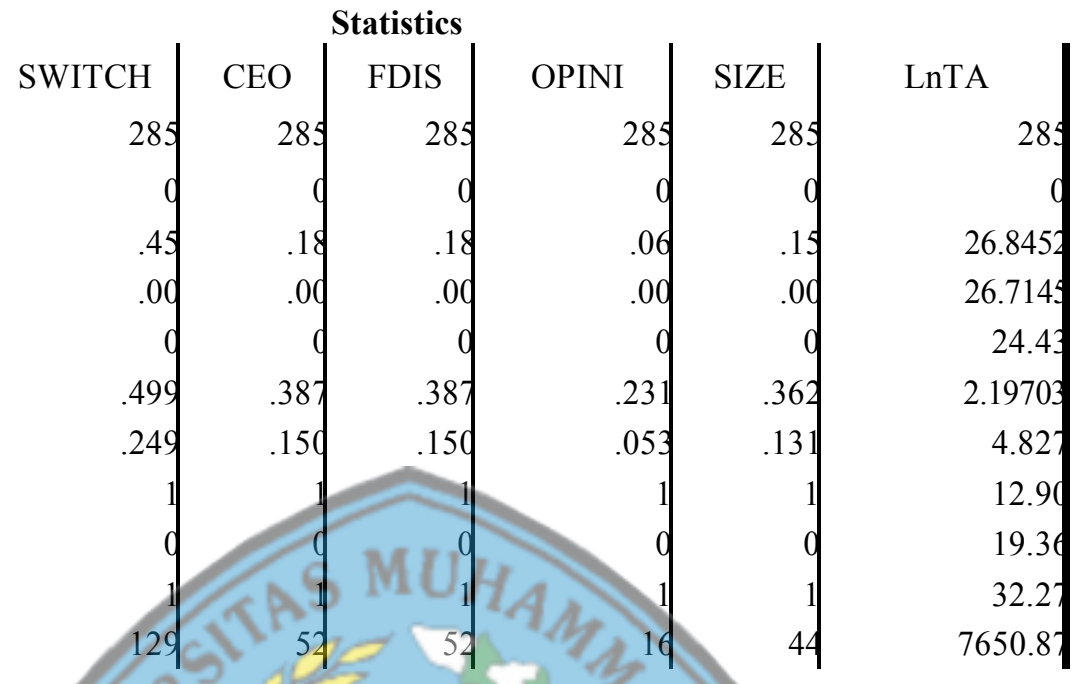

Sumber: output SPSS

Berdasarkan tabel 2 dapat dijelaskannilai mean, median, mode, standar deviasi, varians, nilai minimum, nilai maksimum, dan sum dari seluruh variabel.

1. Pergantian Kantor Akuntan Publik (KAP)

Tabel 3

Hasil Analisis Frekuensi SWITCH
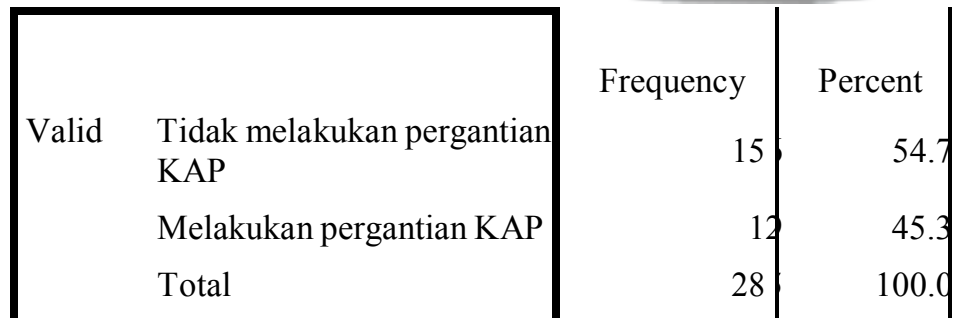

\begin{tabular}{r|r|}
$\begin{array}{c}\text { Valid } \\
\text { Percent }\end{array}$ & $\begin{array}{r}\text { Cumulative } \\
\text { Percent }\end{array}$ \\
54.7 & 54.7 \\
45.3 & 100. \\
100.9 &
\end{tabular}

Sumber: output SPSS

Berdasarkan tabel 3 dapat diketahui bahwa frekuensi unit analisis yang tidak melakukan pergantian KAP adalah sebesar 156 atau 54,7 persen, sedangkan yang melakukan pergantian KAP adalah sebesar 129 atau 45,3 persen.

1. Pergantian Manajemen 
Tabel 4
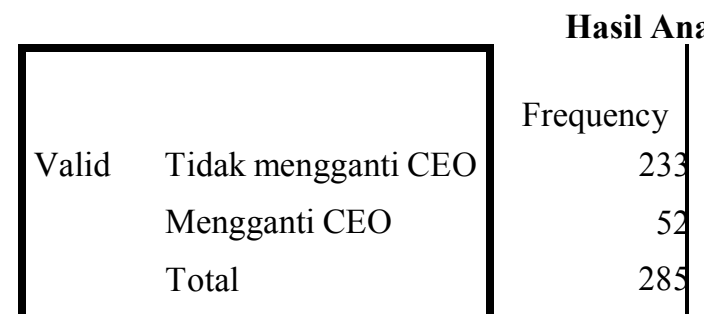

\begin{tabular}{r|r|}
\multicolumn{1}{|c|}{ Pis Frekuensi CEO } \\
Percent & Valid Percent \\
81.8 & 81.8 \\
18.2 & 18.2 \\
100.0 & 100.0
\end{tabular}

Cumulative

Percent

Sumber: output SPSS

Berdasarkan tabel 4 yang menunjukkan penyebaran frekuensi tabulasi data untuk variabel pergantian manajemen, dapat diketahui bahwa frekuensi unit analisis yang tidak mengganti CEO adalah sebanyak 233 atau 81,8 persen, sedangkan yang mengganti CEO adalah sebanyak 52 atau 18,2 persen.

\section{2. $\quad$ Financial Distress}

Tabel 5

Hasil Analisis Frekuensi FDIS

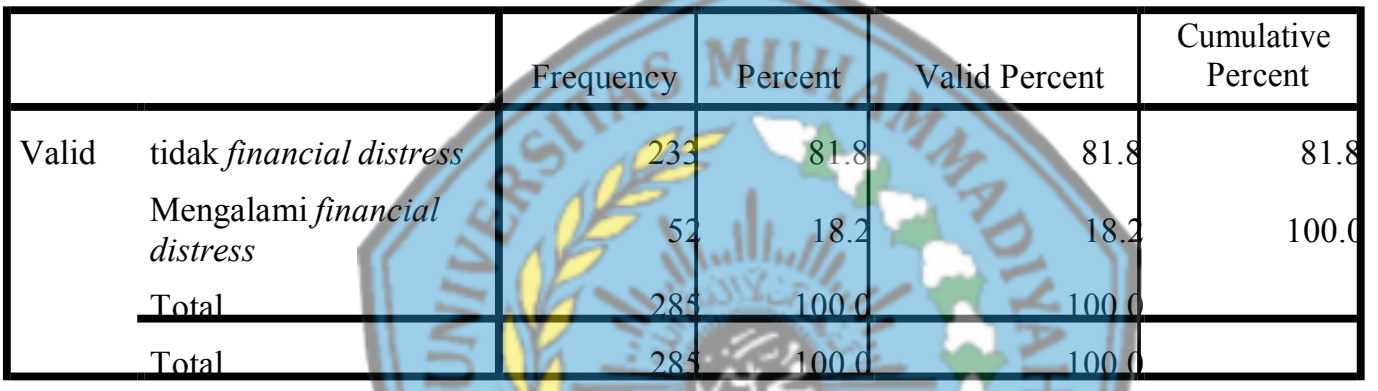

Sumber: output SPSS

Tabel 5 menunjukkan ada 233 atau 81,8 persen unit analisis yang tidak mengalami financial distress, dan 52 atau 18,2 persen unit analisis yang mengalami financial distress.

3. Opini Auditor

\section{Tabel 6}

\section{Hasil Analisis Frekuensi OPINI}

\begin{tabular}{|c|c|}
\hline \multirow[t]{4}{*}{ Valid } & $\begin{array}{l}\text { Opini selain wajar dengan } \\
\text { pengecualian }\end{array}$ \\
\hline & $\begin{array}{l}\text { Opini wajar dengan } \\
\text { pengecualian }\end{array}$ \\
\hline & Total \\
\hline & mber: output SPSS \\
\hline
\end{tabular}

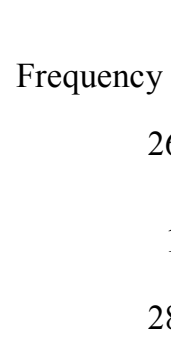

Valid
Percent

$$
\begin{array}{r}
94.4 \\
5.6 \\
100.0
\end{array}
$$

Cumulative Percent

Tabel 6 menunjukkan bahwa terdapat 269 atau sebesar 94,4 persen unit analisis yang mendapatkan opini selain wajar dengan pengecualian, dan sisanya sebanyak 16 atau 5,6 persen mendapatkan opini wajar dengan pengecualian. 
4. Ukuran KAP

Tabel 7

\begin{tabular}{|l|}
\hline Valid $\quad$ KAP non big four \\
KAP big four \\
Total \\
Sumber: output SPSS
\end{tabular}

\section{Hasil Analisis Frekuensi SIZE}

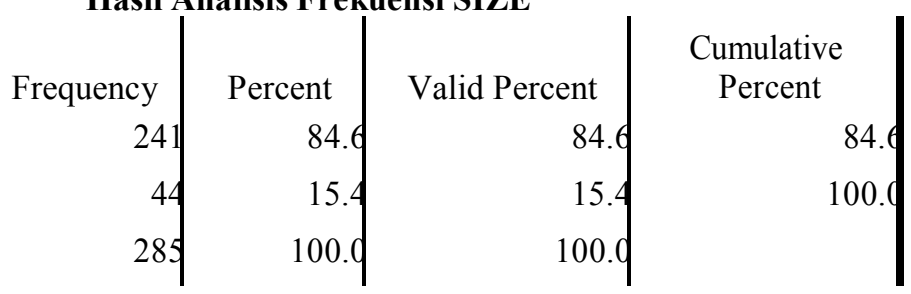

Tabel 7 menunjukkan ada 241 unit analisis atau sebesar 84,6 persen yang menggunakan jasa KAP non big four, dan sisanya sebanyak 44 atau 15,4 persen menggunakan jasa audit dari KAP big four. Menilai Keseluruhan Model (Overall Model Fit)

Tabel 8

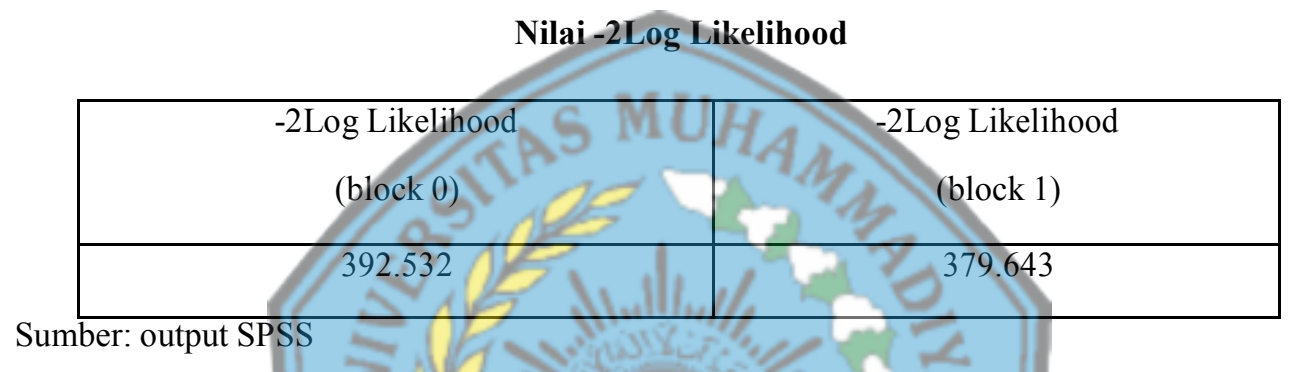

Tabel 8 menunjukkan nilai -2LL awal adalah sebesar 392,532. Setelah dimasukkan kelima variabel independen, maka nilai -2LL akhir mengalami penurunan menjadi 379,643. Penurunan -2LL ini menunjukkan model regresi yang lebih baik atau model yang dihipotesiskan fit dengan data.

Menguji Kelayakan Model Regresi (Hosmer and Lemeshow's Goodness of Fit Test)

\section{SEHA Tabel 9}

\section{Hasil Uji Hosmer dan Lemeshow}

\section{Hosmer and Lemeshow Test}

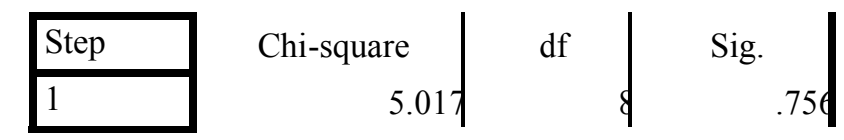

Sumber: output SPSS

Tabel 9 menunjukkan nilai statistik HL sebesar 5.017dengan probabilitas signifikansi 0,756 yang nilainya lebih besar dari 0,05. Hal ini menunjukkan bahwa model sesuai dengan data dan model dapat diterima karena signifikansinya di atas 5\%. Dengan demikian dapat disimpulkan bahwa model mampu memprediksi nilai observasinya.

\section{Koefisien Determinasi (Nagelkerke R Square)}

Nilai Nagelkerke R Squarepada tabel 10adalah sebesar 0,059 yang berarti variabel dependen yang dapat dijelaskan oleh variabel independen adalah sebesar 5,9 persen, sedangkan sisanya sebesar $94,1 \%$ dijelaskan oleh variabel-variabel lain di luar model penelitian. Hasil perhitungan 
Tabel 10

\section{Nagelkerke R Square}

\section{Model Summary}

\begin{tabular}{|l|r|}
\hline Step & -2 Log likelihood \\
\hline 1 & 379.629 \\
\hline
\end{tabular}

Cox \& Snell R Square

Nagelkerke R Square

Sumber: output SPSS

\section{Uji Multikolinieritas}

Tabel 11

Hasil Uji Multikolinieritas

\begin{tabular}{|ll|}
\hline Step 1 & Constant \\
& CEO \\
& FDIS \\
& OPINI \\
SIZE \\
LnTA
\end{tabular}

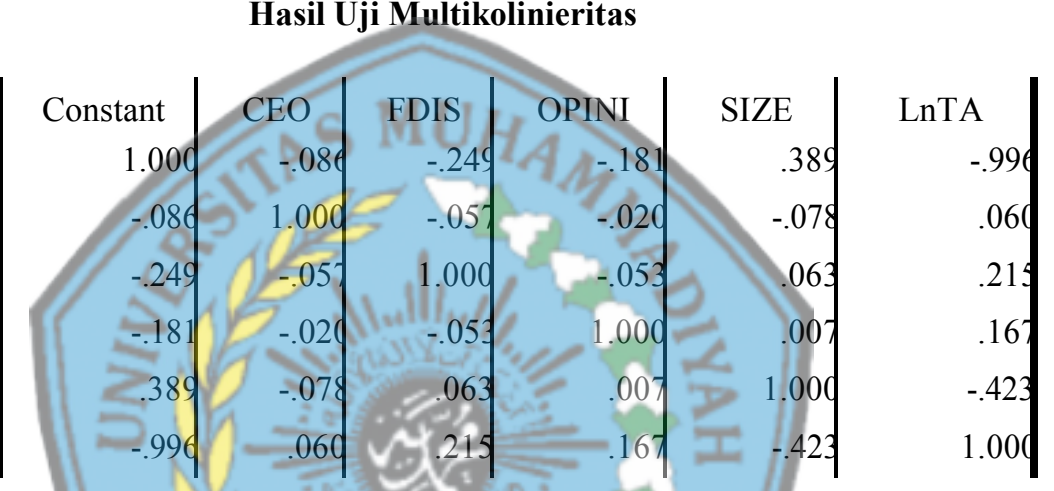

Hasil dari tabel 11 di atas menunjukkan bahwa

dapat dilihat dari korelasi antar variabel tidak ada indikasi terjadinya multikolinieritas independen, dimana tidak ada nilai koefisien antar variabel independennya. Hal ini

korelasi yang nilainya lebih besar dari 0,80 .

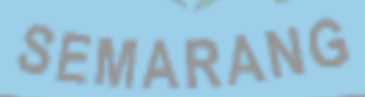

\section{Matriks Klasifikasi}

Tabel 12

\section{Matriks Klasifikasi}

\section{Classification Table ${ }^{\mathrm{a}}$}

\begin{tabular}{|c|c|c|c|c|c|}
\hline \multirow[b]{4}{*}{ Step 1} & \multirow[b]{3}{*}{ Observed } & & \multicolumn{3}{|c|}{ Predicted } \\
\hline & & & \multicolumn{2}{|c|}{ SWITCH } & \multirow[b]{2}{*}{$\begin{array}{c}\text { Percentage } \\
\text { Correct }\end{array}$} \\
\hline & & & $\begin{array}{c}\text { Tidak } \\
\text { melakukan } \\
\text { Pergantian KAP }\end{array}$ & $\begin{array}{c}\text { Melakukan } \\
\text { Pergantian KAP }\end{array}$ & \\
\hline & SWITCH & $\begin{array}{l}\text { Tidak melakukan } \\
\text { pergantian KAP }\end{array}$ & 1 & 1 & 89. \\
\hline
\end{tabular}




\begin{tabular}{|c|c|c|}
\hline KAP & 94 \\
Overall Percentage \\
Sumber: output SPSS
\end{tabular}

Tabel 12menunjukkan bahwa dengan menggunakan model regresi yang digunakan, terdapat sebanyak 35 perusahaan yang diprediksi akan melakukan pergantian kantor akuntan publik (KAP) dari total 123 perusahaan yang melakukanpergantian KAP. Sedangkan kekuatan prediksi model perusahaan yang tidak melakukan pergantian KAPadalah sebesar 89,1 persen, yang berarti bahwa dengan model regresi yang digunakan ada sebanyak 139 perusahaan yang diprediksi tidak melakukan pergantian KAPdari total 156 perusahaan yang tidak melakukan pergantian KAP.

\section{Regresi Logistik}

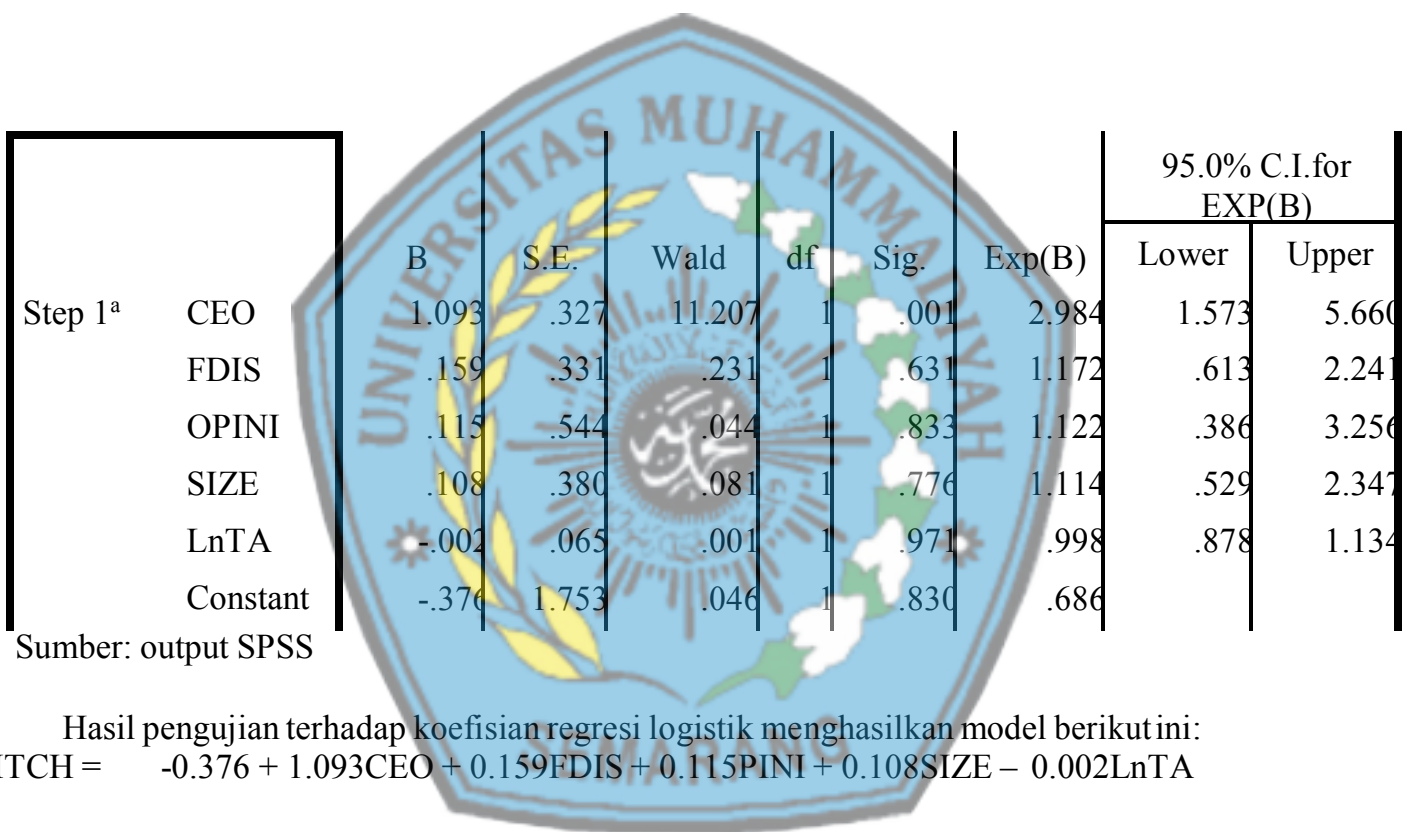

\section{PEMBAHASAN}

\section{Pengaruh Pergantian Manajemen terhadap Pergantian Kantor Akuntan Publik}

Hipotesis 1 menyatakan bahwa pergantian manajemen berpengaruh terhadap pergantian kantor akuntan publik (KAP). Berdasarkan hasil dari pengujian variabel CEO, didapatkan nilai signifikansi pergantian manajemen adalah sebesar 0,001 yang artinya lebih kecil dari taraf signifikansi yaitu 5\%. Berdasarkan nilai signifikansi tersebut dapat di simpulkan bahwa pergantian

manajemen berpengaruh terhadap pergantian KAP.
Hasil penelitian ini selaras dengan hasil penelitian Susan dan Trisnawati (2011), Pratini dan Astika (2013), Dwiyanti dan Sabeni (2014), dan Budi et al (2015). Damayanti dan Sudarma (2010) dalam Pratini dan Astika (2013) menyatakan bahwa pergantian manajemen dapat disebabkan karena pihak manajemen berhenti karena kemauan sendiri atau keputusan rapat umum pemegang saham, sehingga pemegang saham harus melakukan pergantian manajemen yang baru yaitu direktur utama atau Chief Executive Officer (CEO). Dengan adanya CEO yang baru mengakibatkan perubahan pada kebijakan di dalam perusahaan seperti dalam bidang akuntansi keuangan dan pemilihan sebuah KAP karena perusahaan cenderung akan memilih 
auditor baru yang sepakat dengan kebijakan baru di perusahaan mereka.

\section{Pengaruh Financial Distress terhadap Pergantian Kantor Akuntan Publik}

Hipotesis 2 menyatakan bahwa financial distress berpengaruh terhadap pergantian kantor akuntan publik (KAP). Berdasarkan hasil dari pengujian variabel FDIS yang memiliki tingkat signifikansi 0,631, didapatkan bahwa financial distress tidak berpengaruh terhadap pergantian KAP.

Hasil penelitian ini tidak mendukung hasil penelitian sebelumnya yang dilakukan oleh Pratini dan Astika (2013), Dwiyanti dan Sabeni (2014) dan Budi et al (2015). Meskipun demikian, hasil penelitian ini selaras dengan hasil penelitian Susan dan Trisnawati (2011) yang menyatakan bahwa financial distress tidak berpengaruh terhadap pergantian KAP.

Hasil pengujian menunjukkan bahwa financial distress tidak selalu diikuti dengan pergantian KAP. Perusahaan yang mengalami financial distress cenderung tidak melakukan pergantian KAP menjadi KAP big four yang kredibilitasnya tidak tinggi. $\mathrm{Hal}$ tersebut disebabkan karena pergantian auditor pada suatu perusahaan dapat meningkatkan fee auditnya. Pergantian KAP menjadi KAP big four bagi perusahaan yang berpotensi bangkrut memang dapat menarik kepercayaan stakeholders, namun perusahaan cenderung tidak memiliki kemampuan untuk membayar fee audit yang dibebankan oleh KAP sehingga perusahaan lebih memilih untuk tidak mengganti auditornya atau hanya menggunakan jasa KAP lain yang bukan big four.

\section{Pengaruh Opini Auditor terhadap Pergantian Kantor Akuntan Publik}

Hipotesis 3 menyatakan bahwa opini auditor berpengaruh terhadappergantian Kantor Akuntan Publik (KAP). Berdasarkan hasil dari pengujian variabel OPINI yang memiliki koefisien regresi positif 0,115 dengan tingkat signifikansi 0,833 , didapatkan bukti bahwa opini auditor tidak berpengaruh terhadap pergantian KAP.

Hasil penelitian ini tidak mendukung hasil penelitian sebelumnya yang dilakukan oleh Dwiyanti dan Sabeni (2014). Meskipun demikian, hasil penelitian ini sejalan dengan hasil penelitian Susan dan Trisnawati (2011), Pratini dan Astika (2013), dan Juliantari dan Rasmini (2013) yang menyatakan bahwa opini auditortidak berpengaruh secara signifikan terhadap pergantian KAP.
Tidak didukungnya hipotesis yang diuji karena sebagian besar sampel telah mendapatkan opini wajar tanpa pengecualian dan wajar tanpa pengecualian dengan bahasa penjelasan, dan hanya beberapa yang mendapatkan opini wajar dengan pengecualian. Dalam pengujian ini di dapat bahwa perusahaan mendapatkan opini wajar dengan pengecualian tidak selalu diikuti dengan pergantian KAP. Meskipun perusahaan mengganti auditornya, mereka cenderung tetap mendapatkan opini yang sama sehingga perusahaan lebih memilih mempertahankan auditornya .

\section{Pengaruh Ukuran Kantor Akuntan Publik terhadap Pergantian Kantor Akuntan Publik} Dalam penelitian ini, ukuran kantor akuntan publik (KAP) diukur dengan afiliasi dengan KAP big four. Hipotesis 4 menyatakan bahwa ukuran KAP berpengaruh terhadap pergantian KAP. Namun, berdasarkan hasil dari pengujian variabel SIZE yang memiliki koefisien regresi sebesar 0,108 dan tingkat signifikansi 0,776 , didapatkan bukti bahwa ukuran KAP tidak berpengaruh terhadap pergantian KAP.

4.7. Penelitian ini berhasil mendukung penelitian Pratini dan Astika (2013) yang menyatakan bahwa ukuran KAP tidak mempunyai pengaruh yang signifikan terhadap pergantian KAP. Ketidak mampuan dalam membuktikan hasil ini dikarenakan sebagian perusahaan menggunakan jasa KAP big four sebagai jasa auditnya dan cenderung merupakan perusahaan yang besar. Hal tersebut mendukung kemampuan perusahaan untuk membayar fee audit atas jasa auditnya, dimana fee untuk jasa KAP big four lebih besar daripada jasa audit KAP non big four. Alasan lain yang memungkinkan ukuran KAP tidak mempengaruhi pergantian KAP adalah karena perusahaan yang melakukan pergantian auditor, cenderung masih tetap menggunakan KAP dalam kelas yang sama.

\section{Pengaruh Ukuran Klien terhadap Pergantian Kantor Akuntan Publik}

Hipotesis 5 menyatakan bahwa ukuran klien berpengaruh terhadap pergantian Kantor Akuntan Publik (KAP). Berdasarkan hasil dari pengujian variabel LnTA yang memiliki koefisien regresi negatif $-0,002$ dan tingkat signifikansi 0,971, didapatkan bukti bahwa ukuran klien tidak berpengaruh terhadap pergantian KAP.

Penelitian ini gagal membuktikan adanya pengaruh ukuran perusahaan klien terhadap pergantian KAP. Dalam data yang telah dianalisis, diketahui bahwa perusahaan- perusahaan besar dan memiliki operasional yang 
kompleks, cenderung tidak akan mengganti auditornya karena telah menggunakan jasa KAP big four. Hal tersebut dimaksudkan untuk mengurangi agency cost dan mempertahankan kredibilitas perusahaan. Ukuran klien yang kecil, cenderung menggunakan KAP yang kecil pula.

Penelitian ini bertolak belakang dengan penelitian yang dilakukan oleh Juliantari dan Rasmini (2013), Dwiyanti dan Sabeni (2014), dan Budi et al (2015) dimana ketiganya mendapatkan hasil bahwa ukuran klien berpengaruh signifikan terhadap pergantian KAP.

\section{PENUTUP}

\section{Kesimpulan}

Berdasarkan hasil pengujian hipotesis, maka dapat ditarik kesimpulan sebagai berikut:
1. Pergantian manajemen pengaruh yang mempunyai terhadappergantian Kantor Akuntan Publik.

2. Hinancial distress trdak mempunya1

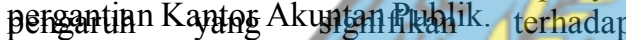

3. Opini auditor tidak mempunyai pengaruh yang signifikan terhadap pergantian Kantor Akuntan Publik.

4. Ukuran KAPtidak mempunyai pengaruh yang signifikan terhadap pergantian Kantor Akuntan Publik.

5. Ukuran klien tidak mempunyai pengaruh yang signifikan terhadap pergantian Kantor Akuntan Publik.

\section{Saran}

1. Bagi perusahaan yang ingin mengganti $R A M\left(\mathrm{C}^{2}\right.$ akurat. auditor atau KAP sebaiknya lebih mempertimbangkan keputusan tersebut lebih matang lagi, karena laporan audit yang diberikan oleh auditor mengenai kewajaran laporan keuangan perusahaan akan menentukan kelangsungan hidup perusahaan karena sangat berkaitan dengan stakeholder-nya.

2. Bagi Kantor Akuntan Publik (KAP) sebaiknya dalam menjalankan audit harus bersikap professional karena keputusan perusahaan untuk melakukan pergantian KAPdipengaruhi oleh profesionalisme KAP.

\section{Keterbatasan Penelitian}

1. Auditor switching dalam penelitian ini hanya memperhatikan pergantian pada tingkat KAP, tidak memperhatikan Jakarta Padang. Jakarta. pergantian pada tingkat auditor independen yang bertanggung jawab terhadap opini audit.

2. Kemampuan variable independen dalam menjelaskan variable dependen masih kecil yaitu 5,9 persen. Nilai yang kecil mengindikasikan masih terdapat banyak variabel independen yang mempengaruhi pergantian Kantor Akuntan Publik.

3. Periode penelitian yang digunakan hanya terbatas lima tahun yaitu tahun 20082012. Periode waktu yang terbatas tersebut tentunya mempengaruhi hasil penelitian ini.

4. Pengukuran financial distress dalam penelitian ini hanya melihat dari perusahaan yang mengalami laba negatif minimal dua tahun berturut-turut, sehingga kurang bisa menggambarkan kondisi kesulitan keuangan yang sedang dialami perusahaan.

\section{DAFTAR PUSTAKA}

Agoes, Sukrisno. 2012. Auditing Petunjuk Praktis Pemeriksaan Akuntan oleh Akuntan Publik Edisi 4 - Buku 1. Penerbit Salemba Empat.

Ahmad, Afridian Wirahadi dan Septriani. 2012. "Konflik Keagenan: Tinjauan Teoritis dan Cara Menguranginya”. Jurnal Akuntansi \& Manajemen Vol 3 No. 2. Politeknik Negeri

Arens, Alvin A. et al. 2006. Auditing dan Jasa Assurance, Jilid 1. Penerbit Erlangga.

Arifah, Dista Amalia. 2012. "Praktek Teori Agensi pada Entitas Publik dan Non 
Publik. Prestasi Vol. 9 No. 1. STIE Bank BPD Jateng.

Boyton, et al. 2002. Modern Auditing, Edisi Ketujuh, Jilid I. Penerbit Erlangga. Jakarta.

Budi, et al. 2015. "Faktor-faktor yang Mempengaruhi Perusahaan Berpindah Kantor Akuntan Publik pada Perusahaan Manufaktur yang Terdaftar di BEI Tahun 2009-2013". Universitas Pandanaran Semarang.

Dwiyanti, R. Meike Erika dan Sabeni. 2014. "Faktor-Faktor yang Mempengaruhi Auditor SwitchingSecara Voluntary". Diponegoro Journal of Accounting Volume 3, Nomor 3.

Endrianto,

Wendy.

2010.

http://lib.ui.ac.id/file?file=digital/132577-

T\%2027743-Analisa\%20pengaruhTinjauan\%20literatur.pdf. Diakses pad tanggal 27 November 2015.

Ghozali, Imam. 2011. Aplikasi Analisis Multivariate dengan Program IBM SPSS. Badan Penerbit Universitas Diponogoro. Semarang.

Guy, M. Dan et al. 2002. Auditing. Penerbit Erlangga. Jakarta.

Juliantari, Ni Wayan Ari dan Rasmini. 2013 "Auditor Switching dan Faktor-Faktor yang Mempengaruhinya.E-Jurnal

Akuntansi Universitas Udayana 3.3. Jlfrnin, Maria. 2014. "Pengaruh Ukuran

Jusup, Al. Haryono, 2001. Auditing. Penerbit Sekolah Tinggi Ilmu Ekonomi YKPN. Yogyakarta.

Kurniaty, Vina et al.. 2014. "Pengaruh Pergantian Manajemen, Opini Audit, Financial Distress, Ukuran KAP, dan Ukuran Perusahaan Klien terhadap Auditor Switching pada Perusahaan Real Estate dan Properti di Bursa Efek Indonesia". JOM FEKON Vol. 1 No 2. 2014

Menteri Keuangan. 2003. Keputusan Menteri Keuangan Nomor 359/KMK.06/2003 tentang "Perubahan Atas Keputusan Menteri Keuangan Nomor 423/KMK.06/2002 tentang Jasa Akuntan Publik".

http://www.sjdih.kemenkeu.go.id/fullText/ 2003/359 KMK.06 2003Kep.html.

Diakses pada tanggal 27 November 2015 .

Menteri Keuangan. 2008. Peraturan Menteri Keuangan Nomor 17/PMK.01/2008 tentang "Jasa Akuntan Publik".http://pppk.kemenkeu.go.id/Doku
men/GetPdfFile?fileName $=6 . \% 20 \mathrm{PMK} \% 2$

0Nomor\%2017\%20tahun\%202008.pdf.

Diakses pada tanggal 27 November 2015.

Pratini, I G A Asti dan Astika. 2013. "Fenomena Pergantian Auditor di Bursa Efek Indonesia”. E-Jurnal Akuntansi Universitas Udayana, 470-482.

Putri, Sonya Mawariani, et al. 2015. "FaktorFaktor yang Mempengaruhi Perusahaan Melakukan Auditor Switching”. Universitas Riau.

Salim, Apriyeni dan Rahayu. 2014. "Pengaruh Opini Audit, Ukuran KAP, Pergantian Manajemen, Financial Distress terhadap Auditor Switching". Univesitas Telkom.

Sarumpaet, Susi. 2010. "Faktor-faktor yang Mempengaruhi Pergantian Auditor oleh Perusahaan yang Terdaftar di Bursa Efek Indonesia". Fakultas Ekonomi Universitas Lampung.

Susan dan Trisnawati. 2011. "Faktor-Faktor yang Mempengaruhi Perusahaan Melakukan Auditor Switch". Jurnal Bisnis dan Akuntansi Vol. 13, No. 2.

Syahtiadi, Fachmy dan Medyawati. 2012. "Analisis Hubungan Auditor-Klien: Faktor-Faktor yang Mempengaruhi Auditor Switching di Indonesia”. Universitas Gunadarma Perusahaan Klien, Opini Audit, Ukuran KAP, Pergantian Manajemen terhadap Auditor Switching: Studi Empiris pada Perusahaan Perbankan yang Terdaftar di Bursa Efek Indonesia". Undergraduate Thesis. Universitas Islam Negeri Maulana Malik Ibrahim Malang.

Utami, Sri dan Prastiti. 2011. "Pengaruh Karakteristik Perusahaan terhadap Social Disclosure". Jurnal Ekonomi Bisnis, Th. 16, No. 1. Fakultas Ekonomi Universitas Negeri Malang.

Wahyuningsih, Nur dan Suryanawa. 2012. "Analisis Pengaruh Opini Audit Going Concern dan Pergantian Manajemen pada Auditor Switching". Jurnal Akuntansi dan Bisnis. Universitas Udayana.

Wijaya, R. M. Aloysius. 2011. "Faktor - Faktor yang Mempengaruhi Pergantian Audtor oleh Klien”. Skripsi. Universitas Brawijaya. Malang.

Wijayani, Evi Dwi dan Januarti. 2011. “Analisis Faktor-Faktor yang Mempengaruhi 
Perusahaan di Indonesia Melakukan Auditor Switching". Simponsium Nasional
Akuntansi XIV Aceh.

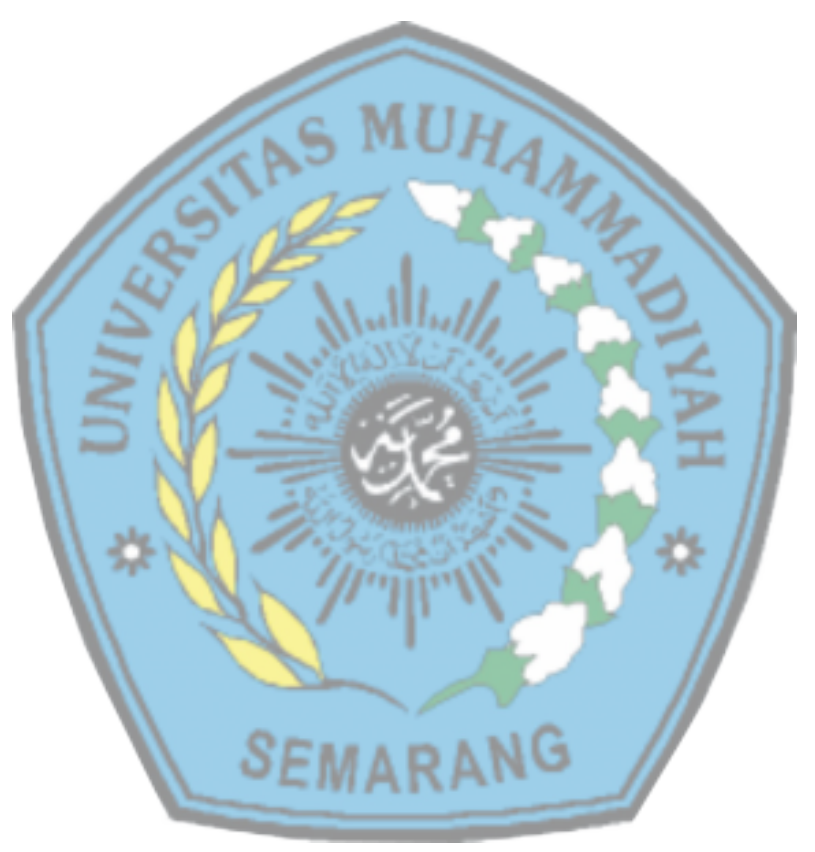

Pergantian Kantor Akuntan...

Hernyke Alviani Sembiring Meliala, Ardiani Ika Sulistyawati 